\title{
Identification and Localization of Muscarinic Acetylcholine Receptor Proteins in Brain with Subtype-specific Antibodies
}

\author{
Allan I. Levey, ${ }^{1,2,5}$ Cheryl A. Kitt, ${ }^{2}$ William F. Simonds, ${ }^{4}$ Donald L. Price, ${ }^{1,2,3}$ and Mark R. Brann ${ }^{5, a}$ \\ Departments of ${ }^{1}$ Neurology, ${ }^{2}$ Pathology, and ${ }^{3}$ Neuroscience, The Johns Hopkins University School of Medicine, Baltimore, \\ Maryland 21205, “Metabolic Diseases Branch, The National Institute of Diabetes, Digestive, and Kidney Diseases, and \\ 5 Laboratory of Molecular Biology, National Institute of Neurological Diseases and Stroke, National Institutes of Health, \\ Bethesda, Maryland 20892
}

mRNAs encoding five genetically distinct muscarinic ACh receptors are present in the CNS. Because of their pharmacological similarities, it has not been possible to detect the individual encoded proteins; thus, their physiological functions are not well defined. To characterize the family of proteins, a panel of subtype-selective antibodies was generated against recombinant muscarinic receptor proteins and shown to bind specifically to each of the cloned receptors. Using immunoprecipitation, three receptor proteins $\left(\mathbf{m}_{1}, \mathbf{m}_{\mathbf{2}}\right.$, and $m_{4}$ ) accounted for the vast majority of the total solubilized muscarinic binding sites in rat brain. These receptor subtypes had marked differences in regional and cellular localization as shown by immunocytochemistry. The $m_{1}-$ protein was present in cortex and striatum and was localized to cell bodies and neurites, consistent with its role as a major postsynaptic muscarinic receptor. The $\mathrm{m}_{\mathbf{2}}$-receptor protein was abundant in basal forebrain, scattered striatal neurons, mesopontine tegmentum, and cranial motor nuclei; this distribution is similar to that of cholinergic neurons and suggests that $m_{2}$ is an autoreceptor. However, $m_{2}$ was also present in noncholinergic cortical and subcortical structures, providing evidence that this subtype may presynaptically modulate release of other neurotransmitters and/or function postsynaptically. The $m_{4}$-receptor was enriched in neostriatum, olfactory tubercle, and islands of Calleja, indicating an important role in extrapyramidal function. These results clarify the roles of these genetically defined receptor proteins in cholinergic transmission in brain. Since the nonselective muscarinic drugs used in the treatment of patients with neurological disease produce many side effects, the

\footnotetext{
Received Mar. 20, 1991; revised May 14, 1991; accepted May 16, 1991.

We thank Drs. Solomon Snyder and Joseph Coyle for reviewing the manuscript; Craig Heilman, Helen Fedor, Sharon Edmunds, and David Gdula for expert technical assistance; Frank Dorje for evaluating antisera; and Norman Nash for synthesis of oligonucleotides. This work was supported by grants from the U.S. Public Health Service (NIH AG 03359, AG 05146), The Robert L. and Clara G. Patterson Trust, and I he Metropolitan Life Foundation. D.L.P. is the recipient of a Javits Neuroscience Investigator Award (NIH NS 10580) and a Leadership and Excellence in Alzheimer's Disease (LEAD) award (NIA AG 07914). A.I.L. is the recipient of a Clinical Investigator Development Award (NIH NS 01387) and a Faculty Scholar Award from the Alzheimer's Disease and Related Disorders Association.

Correspondence should bc addressed to Dr. Allan Levey, Department of Neurology, The Johns Hopkins University School of Medicine, 509 Pathology Building, 600 North Wolfe Street, Baltimore, MD 21205

a Present Address: Department of Psychiatry, University of Vermont, Burlington, VT 05405.

Copyright (C) 1991 Society for Neuroscience $0270-6474 / 91 / 113218-09 \$ 05.00 / 0$
}

characterization of receptor subtypes, including cellular and subcellular localization, will be of great value in defining the targets for the development of more effective and specific therapeutic agents.

In the CNS, muscarinic ACh receptors mediate many functions (e.g., memory, learning, arousal, and motor control), and drugs acting at these sites have potential value in the treatment of a number of neurological disorders involving cholinergic systems, including Alzheimer's disease and Parkinson's disease. Recently, five genes that encode highly related muscarinic receptor proteins $\left(m_{1}-m_{5}\right)$ have been identified (Kubo et al., 1986; Bonner et al., 1987, 1988; Peralta et al., 1987). The proteins have seven putative membrane-spanning regions that are characteristic of the superfamily of $\mathrm{G}$-protein coupled receptors and exhibit functional differences: $m_{1}, m_{3}$, and $m_{s}$ preferentially activate phospholipase $C$ via a pertussis toxin-insensitive $G$-protein; $m_{2}$ and $\mathrm{m}_{4}$ inhibit adenylyl cyclase activity via a pertussis toxin-sensitive G-protein (Peralta et al., 1988; Hulme et al., 1990; Wess et al., 1990). Similarly, the receptors selectively modulate a variety of ion channels (Fukuda et al., 1988; Jones et al., 1988a,b; Higashida et al., 1990; Hulme et al., 1990). The five mRNAs have distinct distributions in brain (Buckley et al., 1988; Weiner et al., 1990), further highlighting the possible functional differences among the subtypes. However, direct characterization of the receptor proteins in the nervous system has been limited by the complex pharmacological properties of the subtypes (Peralta et al., 1987; Akiba et al., 1988; Buckley et al., 1989; Dorje et al., 1991). For example, even the most selective ligands available, such as pirenzepine, which have been used to define pharmacologically distinct binding sites (Hammer et al., 1980), have similar affinities for multiple cloned receptor subtypes (Peralta et al., 1987; Buckley et al., 1989; Hulme et al., 1990; Dorje et al., 1991). Therefore, the relative abundance, localization, and functions of the native muscarinic receptor proteins in the nervous system are presently unknown. A better understanding of this gene family may lead to the development of more effective and specific therapies for many neurologic and psychiatric diseases.

We have recently developed a strategy using molecular and immunological techniques to produce subtype-specific antisera to recombinant muscarinic receptor proteins (Levey et al., 1990). In the present study, we have produced soluble muscarinic receptor fusion proteins in bacteria, incorporating large regions of the nonconserved third cytoplasmic (i3) loops of the human 
sequences. Antisera to these fusion proteins are shown to react highly specifically with each of the five cloned receptor subtypes. Using these antisera, the genetic subtypes of muscarinic receptor proteins in rat brain are directly characterized by immunoprecipitation and immunocytochemistry.

\section{Materials and Methods}

Construction of expression plasmids. Segments of the human muscarinic receptor genes $m_{1}, m_{2}, m_{4}$, and $m_{5}$ were subcloned into the bacterial expression vector pGEX2T (Smith and Johnson, 1988), as described previously for the $\mathrm{m}_{3}$ receptor (Levey et al., 1990). Oligonucleotide primers (51 bases), synthesized on an Applied Biosystems DNA synthesizer, were used in polymerase chain reactions (PCR) in the presence of cloned templates to amplify DNA sequences encoding the i 3 loops of each receptor subtype as described previously (Levey et al., 1990). Restriction sites for BamHI and EcoRI were incorporated into the primers at the $5^{\prime}$ and $3^{\prime}$ ends of the gene fragments, respectively, except for $\mathrm{m}_{2}$, which contains an internal BamHI site and was thus replaced by a BglII site at the $5^{\prime}$ end. In addition, stop codons were placed in the $3^{\prime}$ oligonucleotide to ensure that no additional amino acids were translated. The sequences of the oligonucleotide primers were $m_{1}$ (sense), $5^{\prime}$-AGG TCC GGA TCC GAG ACG CCA GGC AAA GGG GGT GGC AGC AGC AGC AGC TCA; $m_{1}$ (antisense), 5'-AGG TCC GAA TTC ACT TCC GCT TGG CAG CTG CTC CTT TCC ACG GGG CTT CTG; $\mathrm{m}_{2}$ (sense), 5'-CGA TCG AGA TCT GTT GCC AAC CAA GAC CCC GTT TCT CCA AGT CTG GTA; $m_{2}$ (antisense), 5'-AGG TCC GAA TTC ACT GCT TTT CAT CTC CAT TCT GAC CTG AAG ACC CCA CTA; $m_{4}$ (sense), 5'-AGG TCC GGA TCC CCG AAG GAG AAG AAA GCC AAG ACG CTG GCC TTC CTC AAG; $m_{4}$ (antisense), 5-AGG TCC GAA TTC AGC GCA CCT GGT TGC GAG CGA TGC TGG CGA ACT TGC GGG; $m_{5}$ (sense), 5'-AGG TCC GGA TTC AAA GCT GAG AAG AGA AAG CCA GCT CAT AGG GCT CTG TTC; and $\mathrm{m}_{5}$ (antisense), 5' AGG TCC GAA TTC ACA TTT GAT GGC TGG GGT TGG GAT TGA GGC CTT TCG TTG. PCR amplification of the DNA, isolation and restriction digestion of the fragments, and subcloning were all performed using standard procedures (Sambrook et al., 1989). The fragments were subcloned into the BamHI-EcoRI multiple cloning site on pGEX2T. Recombinant plasmids were verified to be in frame by double-stranded dideoxy sequencing (Kraft et al., 1988). The pGEX2T vector encodes the $27.5 \mathrm{kDa}$ glutathione $S$-transferase (GST; EC 2.5.1.18, from Schistosoma japonicum) fused to the N-terminus of the muscarinic i3 loops. Transcription of the fusion sequences are under tac promoter regulation, and inducible with isopropylthiogalactoside (IPTG).

Induction and purification of muscarinic i3 fusion proteins in Escherichia coli. Strain BL21(DE3)pLysS was used to express the fusion proteins as described (Smith and Johnson, 1988; Levey et al., 1990). Briefly, the bacteria were transformed with either a recombinant or parent vector and grown in $400 \mathrm{ml}$ of LB broth containing $100 \mu \mathrm{g} / \mathrm{ml}$ ampicillin and $50 \mu \mathrm{g} / \mathrm{ml}$ chloramphenicol to an optical density of 0.4 , and then the fusion proteins were induced with $1 \mathrm{mM}$ IPTG for 3-4 hr. Cultures were harvested, and the cell pellets were washed with $10 \mathrm{ml}$ of buffer A (50 mM Tris, pH 8.0, $10 \mathrm{~mm}$ EDTA, 25\% sucrose), frozen and thawed, resuspended in $12 \mathrm{ml}$ of buffer A containing $40 \mathrm{mg}$ of lysozyme, and incubated on ice $1 \mathrm{hr}$. The suspension was centrifuged, and the cell pellet was resuspended in $10 \mathrm{ml}$ of buffer $B$ ( $10 \mathrm{~mm}$ Tris, $1 \mathrm{mM}$ EDTA, $1 \mathrm{~mm}$ dithiothreitol) containing a protease inhibitor mixture (1 mM phenylmethylsulfonyl fluoride, $0.2 \mathrm{mg} / \mathrm{ml}$ aprotinin, $1 \mu \mathrm{g} / \mathrm{ml}$ leupeptin, and 1 $\mu \mathrm{g} / \mathrm{ml}$ pepstatin), repeatedly frozen and thawed, and mixed with $25 \mathrm{ml}$ of buffer C (20 mM HEPES, pH 7.6, $100 \mathrm{~mm} \mathrm{KCl,} \mathrm{0.2} \mathrm{mM} \mathrm{EDTA,} \mathrm{20 \%}$ glycerol) containing protease inhibitors, and $4 \mathrm{ml}$ of $10 \%$ Triton X-100. The solubilized fusion proteins were affinity purified by batch procedure using $4 \mathrm{ml}$ of reduced glutathione-agarose beads $(50 \%$ slurry; Sigma Chemical Co.) equilibrated in buffer $\mathrm{C}$, mixed for $2 \mathrm{hr}$ at $4^{\circ} \mathrm{C}$, and washed five times with $20 \mathrm{ml}$ of cold buffer $\mathrm{C}$ containing protease inhibitors. The fusion proteins were eluted with buffer $C$ containing $5 \mathrm{~mm}$ reduced glutathione, $\mathrm{pH} 7.5$, and the fractions were analyzed by SDS-PAGE, pooled, and dialyzed into buffer B using Centriprep chambers (Millipore).

Immunization of rabbits and affinity purification of antisera. Each fusion protein was injected into two female New Zealand White rabbits. Initially, animals received $200 \mu \mathrm{g}$ of affinity-purified fusion protein (in $0.75 \mathrm{ml}$ ) emulsified in an equal volume of complete Freund's adjuvant, followed by secondary injections at 3 weeks with the same dose in incomplete Freund's adjuvant, and then were boosted monthly with 50 $\mu \mathrm{g}$ of protein. Blood was obtained by venipuncture at 3 and 4 weeks postboost, and the sera were stored at $-70^{\circ} \mathrm{C}$. For the present studies, antisera taken 10 weeks post-primary immunization $\left[\mathrm{m}_{1}, \mathrm{AL} 14 ; \mathrm{m}_{2}\right.$, AL 17; $\mathrm{m}_{3}, \mathrm{AL} 18 ; \mathrm{m}_{4}, \mathrm{AL} 28$ or AL7 (Levey et al., 1990); and $\mathrm{m}_{5}, \mathrm{AL} 22$ ] were used for immunoprecipitation studies and affinity purified for immunocytochemistry. Affinity purification was performed as described previously (Harlow and Lane, 1988) using the respective purified fusion proteins (2-4 mg) conjugated to Affi-Gel (Sigma). Sera were preadsorbed with $250 \mu \mathrm{g} / \mathrm{ml}$ of purified glutathione $S$-transferase, and immunoprecipitates were clarified prior to affinity purification in order to remove antibodies reactive with the nonmuscarinic portions of the fusion proteins.

Immunoprecipitation studies. Stable CHO-K1 cell lines individually expressing the human muscarinic receptor subtypes $m_{1}-m_{5}$ or dissected regions of rat brain were used for these experiments. Production of the cell lines and characterization of the receptor binding properties have been previously described (Buckley et al., 1989; Dorje et al., 1991). The total number of receptors/mg of membrane protein (determined by saturation binding) for each subtype is $\mathrm{m}_{1}, 2518 \mathrm{fmol} ; \mathrm{m}_{2}, 747 \mathrm{fmol}$; $\mathrm{m}_{3}, 1831 \mathrm{fmol} ; \mathrm{m}_{4}, 1778 \mathrm{fmol}$; and $\mathrm{m}_{\mathrm{s}}, 954 \mathrm{fmol}$. Animal care was performed in accordance with institutional guidelines. Two male SpragueDawley rats were decapitated, and the brain regions were dissected, pooled, and assayed the same day. Dissected regions included (1) cortex, including the cortical mantle (minus olfactory bulb) and hippocampus (dorsal and ventral); (2) striatum, including caudate-putamen, accumbens, olfactory tubercle, globus pallidus, and basal forebrain; (3) thalamus, including most of the dorsal thalamus and habenula; and (4) hindbrain, including pons, medulla, and cerebellum. Membranes from the cell lines and brain were prepared as described previously (Luthin et al., 1988). Receptors were solubilized by resuspending membranes (to $1.0 \mathrm{mg} / \mathrm{ml}$ protein) in $10 \mathrm{~mm}$ Tris $/ 1.0 \mathrm{~mm}$ EDTA (TE) buffer containing $1.0 \%$ digitonin and $0.2 \%$ cholic acid and labeled with ${ }^{3} \mathrm{H}-N$ methylscopolamine ( $\left.{ }^{3} \mathrm{H}-\mathrm{NMS} ; 1.0 \mathrm{nM}\right)$. Receptors $(195 \mu \mathrm{l})$ were mixed with $5 \mu \mathrm{l}$ of antisera to $m_{1}-m_{s} i 3$ fusion proteins and coprecipitated with goat antirabbit immunoglobulin, and radioactivity in the immunoprecipitates was determined (Levey et al., 1990). Nonspecific trapping of receptors in immunoprecipitates was determined using control antisera [nonspecific rabbit serum (NRS)] raised against a fusion protein without a muscarinic receptor moiety. Total soluble receptors were determined by gel filtration on G-25 Sephadex and were corrected for nonspecific binding in the presence of $1 \mu \mathrm{M}$ atropine.

Immunocytochemistry. Fourteen male albino rats (Charles River, 250$350 \mathrm{gm}$ ) were deeply anesthetized with $4 \%$ chloral hydrate and perfused intracardially with $0.9 \%$ saline, followed by $0.1 \mathrm{M}$ phosphate-buffered $3 \%$ paraformaldehyde, $\mathrm{pH} 7.6$. The brains were immediately removed and cryoprotected in $30 \%$ sucrose in $0.1 \mathrm{~m}$ phosphate buffer ( $\mathrm{pH} 7.6$ ) overnight at $4^{\circ} \mathrm{C}$, frozen on dry ice, and sectioned at $40 \mu \mathrm{m}$ on a freezing sliding microtome. Tissue sections were processed for immunocytochemistry using the peroxidase-antiperoxidase method as previously described (Kitt et al., 1984). Affinity-purified antibodies were used at $0.5 \mu \mathrm{g} / \mathrm{ml}$. Immunocytochemical controls consisted of adsorption of the antibodies with $100 \mu \mathrm{g} / \mathrm{ml}$ of GST or the muscarinic i3 fusion proteins for $20 \mathrm{~min}$ prior to staining. An additional series of sections was incubated in normal rabbit immunoglobulin $(1.0 \mu \mathrm{g} / \mathrm{ml})$. All sections were dehydrated through a graded series of alcohols and xylenes and coverslipped for microscopic examination.

\section{Results}

\section{Muscarinic i3 loop fusion proteins}

Soluble fusion proteins incorporating the i3 loops of the five muscarinic receptors were obtained in high yields (10-25 mg/ liter) from cultures of $E$. coli transfected with the recombinant plasmids (Fig. 1). Two or more protein bands were seen with each of the purified preparations; smaller proteins may represent degradation products. We have also observed shortened products with expression of other recombinant pGEX2T plasmids (A. I. Levey, unpublished observations). The proteins migrated in the range of mobilities expected after fusion with the 27.5 $\mathrm{kDa}$ GST, given that the cloned segments of the $\mathrm{i} 3$ loops encode the following number of amino acids: $\mathrm{m}_{1}, 126 ; \mathrm{m}_{2}, 135 ; \mathrm{m}_{3}$, $193 ; \mathrm{m}_{4}, 152 ; \mathrm{m}_{5}, 99$. 


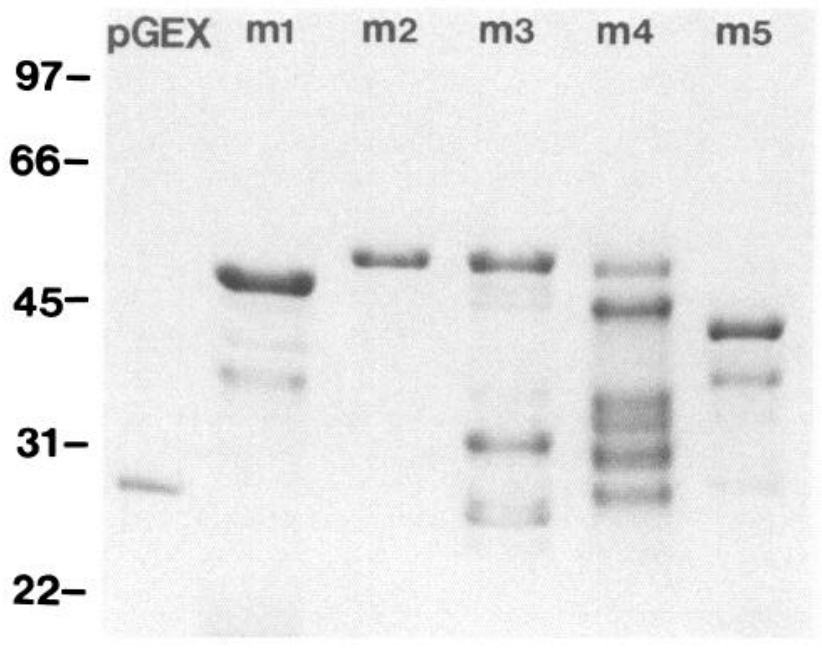

Figure 1. Coomassie blue-stained 10\% SDS-PAGE analysis of affinitypurified muscarinic receptor i3 loop fusion proteins. Approximately 1 $\mu \mathrm{g}$ of GST [encoded by the pGEX2T ( $p G E X)$ parental plasmid] or 10 $\mu \mathrm{g}$ of the i3 loop fusion proteins $m l-m 5$ were loaded in the lanes as marked. Migration of molecular weight markers (in $\mathrm{kDa}$ ) is indicated on the left.

\section{Characterization of subtype-specific antisera}

The specificities of antisera raised against the muscarinic i3 loop fusion proteins were tested by immunoprecipitation of cloned muscarinic receptor subtypes expressed in stably transfected CHO-K1 cells (Table 1). The receptors were individually solubilized with detergent, labeled with ${ }^{3} \mathrm{H}-\mathrm{NMS}$, a ligand that binds with high affinity to all five subtypes, and immunoprecipitated with antisera raised against the fusion proteins. Each receptor subtype was immunoprecipitated by a single antiserum corresponding to the homologous fusion protein used for immunization. Heterologous antiserum-receptor pairs showed little or no binding above background levels (nonspecific trapping in control immunoprecipitates using antisera raised against a fusion protein not containing a muscarinic receptor polypeptide). The relatively small differences (three- to fourfold) in total receptors per assay were due to differences in levels of expression in the cell lines. Antibody binding did not inhibit receptorligand interaction since the reversibly bound ${ }^{3} \mathrm{H}-\mathrm{NMS}$ was directly recovered in the immunoprecipitates; other experiments also showed no inhibition of the antibodies in a soluble receptor binding assay using the same radioligand. The $\mathrm{m}_{1}{ }^{-}$and $\mathrm{m}_{3^{-}}$receptors were quantitatively recovered, and the other subtypes were also precipitated with a high degree of efficiency. Other experiments with fewer receptors demonstrated almost complete recovery of $\mathrm{m}_{2}(87 \%$ of $24 \mathrm{fmol})$ and $\mathrm{m}_{4}(97 \%$ of $9 \mathrm{fmol})$. These experiments demonstrated that antibodies generated against recombinant i3 loops were able to bind quantitatively the functional muscarinic receptors with virtually complete subtype specificity.

\section{Immunoprecipitation of muscarinic receptor subtypes from rat brain}

The direct identification of the genetically defined muscarinic receptor subtypes in rat brain and their regional distributions were determined by immunoprecipitation (Table 2). Three receptors, $\mathrm{m}_{1}, \mathrm{~m}_{2}$, and $\mathrm{m}_{4}$, the major subtypes solubilized from brain, showed marked regional variability. For example, cortical tissues contained higher levels of $\mathrm{m}_{1}$ - and $\mathrm{m}_{2}$-receptors $(40 \%$ each) and lower levels of the $\mathrm{m}_{4}$-subtype $(15 \%)$. There were no major differences between neocortex and hippocampus when assayed separately (data not shown). The striatum (a composite of neostriatum, nucleus accumbens, globus pallidus, basal forebrain, and olfactory tubercle) showed similar amounts of $m_{1}$-, $\mathrm{m}_{2^{-}}$, and $\mathrm{m}_{4}$-receptor proteins. The $\mathrm{m}_{2}$-receptor predominated in thalamus, with relatively fewer $m_{1}$ - and $m_{4}$-proteins; $m_{2}$ was the major muscarinic subtype solubilized from hindbrain. The experiments were performed using limiting numbers of total receptors to ensure quantitative binding of the subtypes (determined using the cloned receptors). The $\mathrm{m}_{3}$ - and $\mathrm{m}_{5}$-receptor proteins were not immunoprecipitated from brain, although both subtypes were detected in cells transfected with the respective cDNAs using identical assay conditions (Table 1). Furthermore, we have detected the native $\mathrm{m}_{3}$-receptor protein in glandular tissue using the same conditions and reagents (Dorje et al., in press).

\section{Immunocytochemical localization of muscarinic receptor subtypes}

The three most abundant muscarinic receptor proteins $\left(\mathrm{m}_{1}, \mathrm{~m}_{2}\right.$, and $\mathrm{m}_{4}$ ) characterized by immunoprecipitation were localized with cellular and subcellular resolution using the subtype-specific antibodies (Fig. 2). In general, immunoreactivity typically appeared to be concentrated in the surface membranes of cells or neuritic processes, although the precise localization was difficult to evaluate light microscopically. Cytoplasmic staining was also occasionally evident and was frequently adjacent to the nucleus in the presumed Golgi apparatus. No staining of nuclei or glia was detected with any of the antibodies. Specificity

\begin{tabular}{|c|c|c|c|c|c|c|c|}
\hline \multirow[t]{2}{*}{$\begin{array}{l}\text { Receptor } \\
\text { subtype }\end{array}$} & \multirow{2}{*}{$\begin{array}{l}\text { Total } \\
\text { receptors } \\
\text { (fmol/assay) }\end{array}$} & \multicolumn{6}{|c|}{ Immunoprecipitates (fmol/pellet) } \\
\hline & & NRS & $\mathrm{m}_{1}$ & $\mathrm{~m}_{2}$ & $\mathrm{~m}_{3}$ & $\mathrm{~m}_{4}$ & $\mathrm{~m}_{\mathrm{s}}$ \\
\hline $\mathrm{m}_{1}$ & $44.2 \pm 2.1$ & $2.9 \pm 0.6$ & $49.6 \pm 5.4$ & $2.8 \pm 0.4$ & $2.8 \pm 0.1$ & $2.4 \pm 0.5$ & $2.9 \pm 0.7$ \\
\hline $\mathrm{m}_{2}$ & $38.0 \pm 0.3$ & $1.3 \pm 0.5$ & $1.8 \pm 0.2$ & $28.1 \pm 3.4$ & $1.5 \pm 0.2$ & $1.3 \pm 0.3$ & $2.2 \pm 0.1$ \\
\hline $\mathrm{m}_{3}$ & $11.6 \pm 1.9$ & $0.8 \pm 0.1$ & $0.9 \pm 0.1$ & $0.9 \pm 0.1$ & $13.4 \pm 0.7$ & $0.8 \pm 0.1$ & $0.9 \pm 0.1$ \\
\hline $\mathrm{m}_{4}$ & $40.6 \pm 0.9$ & $1.5 \pm 0.3$ & $1.8 \pm 0.1$ & $1.7 \pm 0.4$ & $1.7 \pm 0.2$ & $27.8 \pm 1.5$ & $1.5 \pm 0.4$ \\
\hline $\mathrm{m}_{5}$ & $15.7 \pm 1.4$ & $2.5 \pm 0.1$ & $2.0 \pm 0.3$ & $2.3 \pm 0.5$ & $1.8 \pm 0.2$ & $2.1 \pm 0.4$ & $12.4 \pm 2.6$ \\
\hline
\end{tabular}

Functional receptors were detergent solubilized from stable CHO-K1 cell lines transfected with each of the five human muscarinic receptor cDNAs, labeled with ${ }^{3} \mathrm{H}-\mathrm{NMS}$, and immunoprecipitated with control serum (NRS) or antisera to the muscarinic receptor $\mathrm{i} 3$ loops $\mathrm{m}_{1}-\mathrm{m}_{\mathrm{s}}$. Shown are the mean $\pm \mathrm{SD}$ of triplicate samples. The homologous receptorantiserum pairs are shown in italics. 


\begin{tabular}{|c|c|c|c|c|c|c|c|}
\hline \multirow[t]{2}{*}{ Region } & \multirow{2}{*}{$\begin{array}{l}\text { Tolal } \\
\text { receptors } \\
\text { (fmol/assay) }\end{array}$} & \multicolumn{6}{|c|}{ Immunoprecipitates (fmol/pellet) } \\
\hline & & NRS & $\mathrm{m}_{1}$ & $\mathrm{~m}_{2}$ & $\mathrm{~m}_{3}$ & $\mathrm{~m}_{4}$ & $\mathrm{~m}_{5}$ \\
\hline Cortex & $47.4 \pm 2.4$ & $1.2 \pm 0.2$ & $\begin{array}{l}20.4 \pm 2.3 \\
(40)\end{array}$ & $\begin{array}{l}18.7 \pm 3.1 \\
(37)\end{array}$ & $\begin{array}{l}1.6 \pm 0.2 \\
(0)\end{array}$ & $\begin{array}{l}8.6 \pm 1.6 \\
(15)\end{array}$ & $\begin{array}{l}1.4 \pm 0.3 \\
(0)\end{array}$ \\
\hline Striatum & $48.8 \pm 2.0$ & $1.2 \pm 0.2$ & $\begin{array}{l}16.6 \pm 2.6 \\
(31)\end{array}$ & $\begin{array}{l}15.2 \pm 1.8 \\
(29)\end{array}$ & $\begin{array}{l}1.4 \pm 0.2 \\
(0)\end{array}$ & $\begin{array}{l}15.4 \pm 4.0 \\
(29)\end{array}$ & $\begin{array}{l}1.4 \pm 0.2 \\
(0)\end{array}$ \\
\hline Thalamus & $41.8 \pm 1.3$ & $1.1 \pm 0.1$ & $\begin{array}{l}3.4 \pm 0.3 \\
(6)\end{array}$ & $\begin{array}{l}21.5+2.3 \\
(49)\end{array}$ & $\begin{array}{l}1.3 \pm 0.2 \\
(0)\end{array}$ & $\begin{array}{l}7.5 \pm 1.7 \\
(15)\end{array}$ & $\begin{array}{l}1.3 \pm 0.3 \\
(0)\end{array}$ \\
\hline Brainstem & $20.6 \pm 2.4$ & $0.9 \pm 0.2$ & ${ }_{(2)}^{1.3} \pm 0.3$ & $\begin{array}{l}18.2 \pm 1.8 \\
(84)\end{array}$ & $\begin{array}{l}1.0 \pm 0.2 \\
(0)\end{array}$ & $\begin{array}{l}1.2 \pm 0.2 \\
(1)\end{array}$ & $\begin{array}{l}1.1 \pm 0.2 \\
\text { (1) }\end{array}$ \\
\hline
\end{tabular}

Total receptors represent solubilized ${ }^{3} \mathrm{H}-\mathrm{NMS}$ binding sites as determined independently by gel exclusion chromatography. Shown are the mean $\pm \mathrm{SD}(n=6)$ from a representative cxpcriment. Numbers in parentheses are the percentages of total receptors specifically bound (minus background values in control immunoprecipitates with NRS concentrations).

was demonstrated by complete inhibition of staining after preadsorption of the antisera with the respective i3 loop fusion proteins (Fig. $2 D^{\prime}-F^{\prime}$ ). Preadsorption of the antisera with GST, the protein common to each of the muscarinic fusion proteins, had no observable effect on staining (data not shown). The $\mathrm{m}_{3}$ and $\mathrm{m}_{5}$-receptors were not detected reliably by immunocytochemistry, in agreement with the immunoprecipitation studies. This might be due to methodological problems (e.g., denaturation of the epitopes by fixation), or possibly lower levels of expression since both mRNAs are present in brain.

In cortex, $\mathrm{m}_{1}-, \mathrm{m}_{2^{-}}$, and $\mathrm{m}_{4}$-immunoreactivities were differentially localized. The $\mathrm{m}_{1}$-immunoreactivity was present in most cortical neurons and was particularly dense in neuropil in layers II/III and VI (Fig. $2 A, D$ ); the laminar distribution of the protein is consistent with the cellular localization of $m_{1}$ mRNA (Buckley et al., 1988; Weiner and Brann, 1989). The $m_{2}$-protein was dense in layer IV and the border of layers V/VI (Fig. $2 B, E$ ). Although initial studies failed to reveal $\mathrm{m}_{2}$-mRNA in cortex (Buckley et al., 1988), more sensitive methods have localized this subtype to cell bodies in a pattern similar to the $\mathrm{m}_{2}$-protein (Weiner and Brann, 1989); however, the $\mathrm{II}_{2}$-protein was associated mostly with fibers and presumptive terminals and only occasionally perikarya. The $\mathrm{m}_{4}$-immunoreactivity, considerably less dense than the other subtypes in cortex, was localized in the neuropil of layers II/III and patches in layer IV (Fig. 2C,F), and in scattered perikarya (mostly layer V). These findings are consistent with the localization of $m_{4}-m_{R N A}$ (Buckley et al., 1988; Weiner and Brann, 1989). The perikaryal immunoreactivity was best visualized with another antibody raised to the denatured form of $\mathrm{m}_{4} \mathrm{i} 3$ (Levcy ct al., 1990) (Fig. $3 E$ ). Regional differences with these subtypes were also evident; for example, $\mathrm{m}_{1}$-immunoreactivity was more abundant in frontoparietal regions than retrosplenial cortex, whereas the converse was true of $m_{2}$. Similarly, in hippocampus, $m_{1}$ was particularly dense in CAl and dentate gyrus, and $\mathrm{m}_{2}$ was more abundant in CA2-4.

The $\mathrm{m}_{1-}, \mathrm{m}_{2}-$, and $\mathrm{m}_{4}$-receptors were differentially localized in the striatum. Immunoreactivities for the $m_{1}-$ and $m_{4}$-receptors were particularly dense and patchy in the neostriatum and nucleus accumbens (Fig. $2 A, C$ ). Discrete perikaryal localization of both receptors may have been obscured by the dense immunoreactivity associated with the neuropil. The $\mathrm{m}_{4}$-protein was also present in the substantia nigra. In the olfactory tubercle, $\mathrm{m}_{1}$ and $\mathrm{m}_{4}$ were present in the neuropil; $\mathrm{m}_{4}$ was particularly dense in the islands of Calleja. The $\mathrm{m}_{2}$-receptor was localized to scattered large neurons in caudate-putamen and nucleus ac- cumbens (Fig. 3). These findings are in register with the localization of $m_{1^{-}}, m_{2^{-}}$, and $m_{4}-m R N A s$ in striatum and olfactory tubercle (Buckley et al., 1988; Weiner et al., 1990; Vilaro et al., 1991). Although immunoprecipitation studies demonstrated approximately equal levels of the three proteins in striatum, immunocytochemistry showed that much of the $m_{2}$-protein in this region was due to enrichment in basal forebrain, including the septum (Fig. 2) and more caudal aspects of cholinergic cell groups $(\mathrm{Ch} 1-4)$. The $\mathrm{m}_{2}$-immunoreactivity was localized in neuronal processes and, to a lesser extent, appeared to be on the surface of cell bodies. The $\mathrm{m}_{2}$-receptor was present at high levels in the anterior and intralaminar nuclei of the thalamus, anterior pretectal nucleus, superior and inferior colliculi, pontine nuclei, many regions of the tegmentum, including pedunculopontine tegmental nucleus and laterodorsal tegmental nucleus, and all motor nuclei of the cranial nerves.

\section{Discussion}

Muscarinic ACh receptors, like other neurotransmitter receptors, including nicotinic $\mathrm{ACh}$, catecholamine, glutamate, and GABA, are encoded by a family of genes. The high degree of relatedness within each family has made it difficult, if not impossible, to use the small pharmacological differences among the subtypes to identify the proteins in tissues. In the present study, we have developed a panel of antibodies that bind the five cloned muscarinic receptors with virtually complete subtype specificity. These antibodies have provided an unprecedented opportunity to characterize a family of genetically defined neurotransmitter receptor proteins. Using immunoprecipitation, three receptor proteins, $m_{1}, m_{2}$, and $m_{4}$, were shown to account for the vast majority of solubilized muscarinic receptor binding sites in brain. The precise cellular and subcellular localization of these proteins by immunocytochemistry has greatly clarified the roles of the muscarinic receptor subtypes in cholinergic function.

The specificity of the antibodies has been established by many independent criteria: (1) the regions of the i3 loops selected for the fusion proteins show virtually no sequence homology among muscarinic subtypes; (2) immunoblotting experiments have verified that the i3 loops are antigenically unrelated (Levey et al., 1990); (3) each antiserum bound a single cloned receptor subtype by immunoprecipitation; (4) the distribution of receptor proteins was similar in both immunoprecipitation and immunocytochemistry experiments; (5) antibody binding was blockable with the homologous i3 loop fusion proteins, but not the pa- 

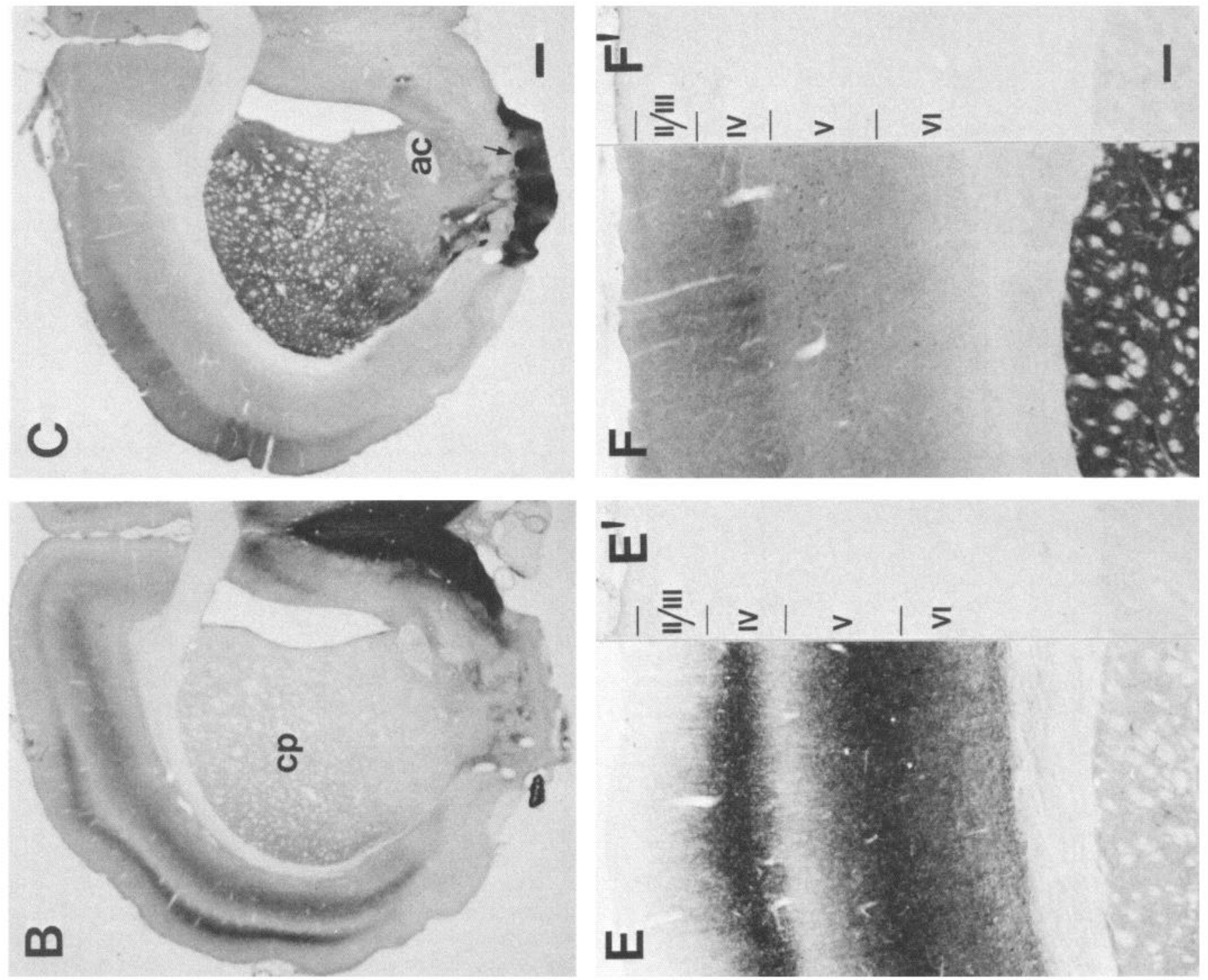

\section{W}
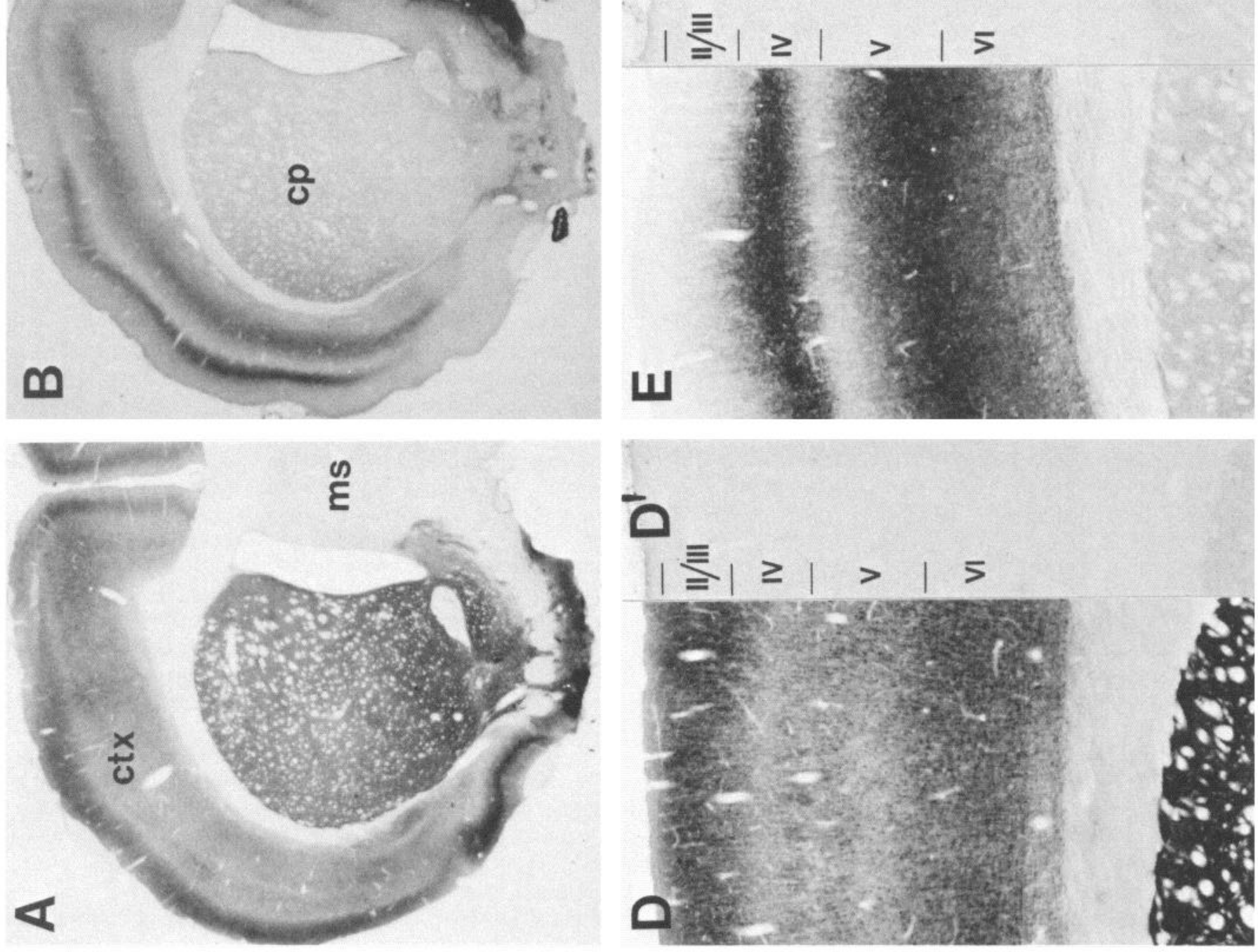
rental fusion protein (minus the i3 loop); (6) the localization of the receptor proteins agreed with the localization of the respective mRNAs (Buckley et al., 1988; Weiner et al., 1990; Vilaro et al., 1991), although, as expected, there were important differences in the subcellular distribution of proteins and mRNAs; and (7) receptor localization $\left(\mathrm{m}_{2}\right)$ was very similar using antipeptide antibodies directed to a completely different region of the protein (A. I. Levey, W. F. Simonds, and M. R. Brann, unpublished observations). Thus, the rigorous evaluation of the antibodies provides a firm basis for analyzing the native receptor subtypes.

Immunological characterization of the muscarinic receptor proteins complements and extends previous in situ hybridization studies (Buckley et al., 1988; Weiner and Brann, 1989; Weiner et al., 1990). Since mRNAs are localized primarily to cell bodies and proximal dendrites, in situ hybridization studies provide clear evidence for the distribution and identity of neurons that synthesize the receptor subtypes. On the other hand, this approach yields no information about the abundance or subcellular distribution of the receptors; these considerations are important because of possible differences in translational efficiencies, turnover, and transport of the proteins. The immunological methods we have developed provide direct information about the relative abundance and precise localization of the subtypes. As summarized in Table 3, for most of the subtypes there is an excellent correspondence between the distributions of mRNA and protein. However, two of the muscarinic receptor proteins, $m_{3}$ and $m_{5}$, whose $m R N A s$ have been identified in brain (Buckley et al., 1988; Weiner and Brann, 1989; Weiner et al., 1990), were not reliably detected in this investigation. These data suggest that $m_{3}$ - and $m_{5}$-proteins may be expressed at very low levels in brain. The subcellular distribution of the receptors also appears to be highly regulated. In some regions, the proteins were clearly localized to perikarya (e.g., $m_{1}$ in cortical neurons and $m_{2}$ in striatum), and as described in Results, these findings were consistent with the distributions of the mRNAs. However, in other instances (e.g., $\mathrm{m}_{2}$ in cortex and $\mathrm{m}_{4}$ in substantia nigra), the proteins were predominantly localized in neurites, fibers, or presumptive terminals. In these cases, knowledge of the distribution of mRNA helps interpret the cellular origin of the subtypes; for example, $\mathrm{m}_{2}$-protein in cortex might be derived from either cortical or basal forebrain cells that express $m_{2}-m R N A$. Similarly, $m_{4}$ is possibly associated with striatonigral terminals, since the $m_{4}$-mRNA is present in medium-sized striatal (projection) ncurons and not in substantia nigra (Weiner et al., 1990). Ultrastructural and lesion analysis will be valuable to evaluate further the compartmentation of the receptors, including synaptic details.

The localization of muscarinic receptors in brain (Yamamura and Snyder, 1974; Kuhar and Yamamura, 1975), including $\mathbf{M}_{1}-$ and $\mathrm{M}_{2}$-pharmacological subtypes (Wamsley et al., 1984; Cortes and Palacios, 1986; Mash and Potter, 1986; Spencer et al., 1986; Regenold et al., 1987), has been extensively studied by ligand autoradiography. Recently, other subtypes have been identified in brain homogenates using pharmacological or kinetic analyses (Doods et al., 1987; Ehlert and Tran, 1990; Waelbroeck et al., 1990). The relation of muscarinic receptor binding sites, defined by various ligands, to the genetically distinct receptor proteins is complicated and uncertain (Peralta et al., 1987; Akiba et al., 1988; Buckley et al., 1989; Dorje et al., 1991). For example, $\mathbf{M}_{1}$-selective ligands, such as pirenzepine, bind with high affinity to $\mathrm{m}_{1}$ - and $\mathrm{m}_{4}$-cloned receptors, and with intermediate affinity to $\mathrm{m}_{3}$ and $\mathrm{m}_{5} . \mathrm{M}_{2}$-selective ligands, such as AFDX-116, also bind with high affinity to multiple subtypes $\left(\mathrm{m}_{2}\right.$ and $\left.\mathrm{m}_{4}\right)$. Therefore, the binding sites localized using these and other selective compounds probably correspond to a minimum of two receptor proteins, although the exact composition would be expected to vary depending on the receptors expressed in the tissue and the binding conditions. Because of the vast amount of information obtained using these pharmacological approaches, it is important to compare the distributions of the pharmacologically defined binding sites with the localization of the gene products, as summarized in Table 3.

$\mathrm{M}_{1}$ receptors, the most abundant pharmacological subtype in cortex and striatum (Cortes and Palacios, 1986; Mash and Potter, 1986; Spencer et al., 1986), are a composite of the $m_{1}$ - and $\mathrm{m}_{4}$-proteins; however, the differential cellular localizations of $\mathrm{m}_{1}$ and $\mathrm{m}_{4}$ suggest that the receptors have important functional differences. Both proteins are abundant in these regions (although $m_{1}$ is relatively higher in cortex than striatum and $m_{4}$ is relatively higher in striatum than cortex), and both have an $M_{1}$-like pharmacology. Moreover, Luthin and Wolfe (Luthin et al., 1988) have shown that pirenzepine $\left(\mathrm{M}_{1}\right)$ binding sites in forebrain are immunoprecipitated by anti-peptide antibodies against $m_{1}$ and that other unidentified receptor proteins are also labeled by this ligand. Using the same strategy, we have immunoprecipitated ${ }^{3} \mathrm{H}$-pirenzepine sites and recovered the ligand with both $\mathrm{m}_{1}$ - and $\mathrm{m}_{4}$-receptors (A. I. Levey, unpublished observations). In cortex, activation of $M_{1}$ receptors leads to phosphatidylinositol hydrolysis (Brown et al., 1984) and inhibition of the M-current (McCormick and Prince, 1985). The preferential coupling of the cloned $\mathrm{m}_{1}$-protein, but not $\mathrm{m}_{4}$, to these signal transduction pathways, together with the relative abundance of $m_{1}$ in cortex, suggests that $m_{1}$-protein accounts for these effects of cortical $\mathbf{M}_{1}$-receptor activation. The immunocytochemical localization of $\mathrm{m}_{1}$, including high levels in superficial laminae of cortex, also matches the pattern of $\mathbf{M}_{\mathbf{1}}$-binding sites (Mash and Potter, 1986; Spencer et al., 1986). The role of the $\mathrm{m}_{4}$-receptor in cortical function, which is localized primarily in the neuropil of superficial layers of cortex and perikarya in layer V, is presently unclear. Since anticholinergics cause cognitive dysfunction in humans (Drachman and Leavitt, 1974)

\section{$\longleftarrow$}

Figure 2. Immunocytochemical localization of $\mathrm{m}_{1}, \mathrm{~m}_{2}$, and $\mathrm{m}_{4}$ receptor proteins in rat cortex, striatum, and basal forebrain. Shown are coronal sections through the forebrain demonstrating muscarinic receptor immunoreactivity using affinity-purified antibodies reactive with the i3 loops of $\mathrm{m}_{1}(A), \mathrm{m}_{2}(B)$, and $\mathrm{m}_{4}(C)$. Note the differential distribution of the three receptors in cortex ( $\left.c t x\right)$, caudate-putamen ( $c p$ ), and olfactory tubercle. The $\mathrm{m}_{2}$ protein is particularly dense in the medial septum $(\mathrm{ms})$, where many cholinergic neurons are located. The arrow points to $\mathrm{m}_{4}$ receptor in an island of Calleja; $a c$ represents anterior commissure. Higher magnification of parietal cortex demonstrates localization of the three receptors $(D$, $\mathrm{m}_{1} ; E, \mathrm{~m}_{2} ; F, \mathrm{~m}_{4}$ ) in cortical laminae as marked. Immunological specificity was confirmed by complete inhibition of staining after preadsorption of the antibodies on the respective fusion proteins $\left(D^{\prime}, \mathrm{m}_{1} \mathrm{i} ; E^{\prime}, \mathrm{m}_{2} 3 ; F^{\prime}, \mathrm{m}_{4} \mathrm{i} 3\right)$. Scale bars: $A-C, 500 \mu \mathrm{m} ;$ and $D-F ; 220 \mu \mathrm{m}$. 

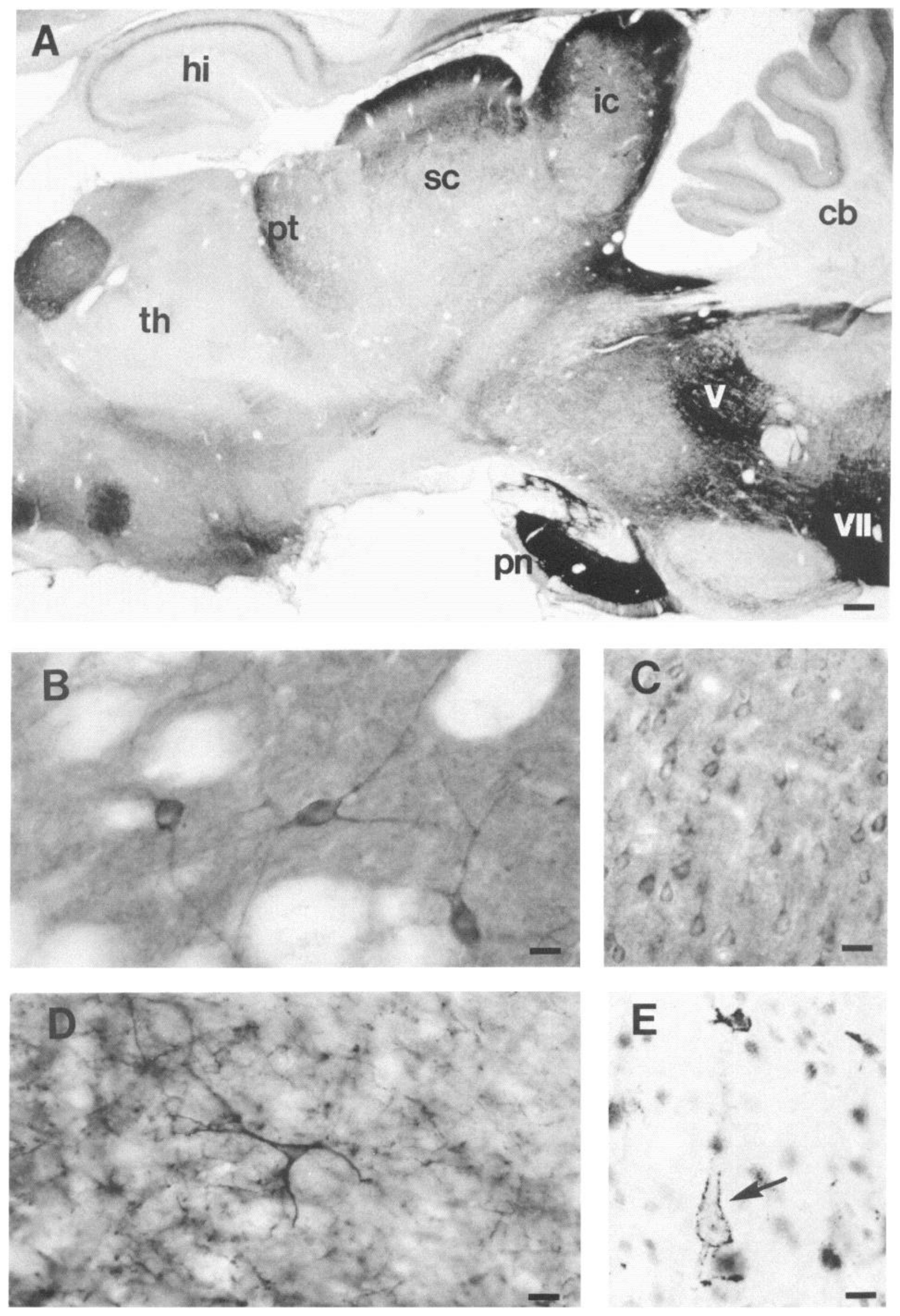
Table 3. Comparison of muscarinic receptor subtype proteins (immunocytochemistry), mRNAs (in situ hybridization), and pharmacological binding sites (autoradiography) in select regions of rat brain

\begin{tabular}{|c|c|c|c|c|c|c|c|c|c|c|}
\hline \multirow[t]{2}{*}{ Brain region } & \multicolumn{3}{|c|}{ Immunocytochemistry } & \multicolumn{5}{|c|}{ In situ hybridization } & \multicolumn{2}{|c|}{ Autoradiography } \\
\hline & $\mathrm{m}_{1}$ & $\mathrm{~m}_{2}$ & $\mathrm{~m}_{4}$ & $\mathrm{~m}_{1}$ & $\mathrm{~m}_{2}$ & $\mathrm{~m}_{3}$ & $\mathrm{~m}_{4}$ & $\mathrm{~m}_{5}$ & $\mathbf{M}_{1}$ & $\mathbf{M}_{2}$ \\
\hline Neocortex & +++ & ++ & + & +++ & ++ & ++ & + & - & $++t$ & ++ \\
\hline Hippocampus & +++ & ++ & + & +++ & + & ++ & ++ & + & +++ & ++ \\
\hline Basal forebrain & - & +++ & - & - & +++ & + & + & - & - & +++ \\
\hline Striatum & +++ & + & +++ & +++ & ++ & - & +++ & - & +++ & + \\
\hline Substantia nigra & - & + & + & - & + & - & - & ++ & + & + \\
\hline Amygdala & ++ & + & + & +++ & + & + & + & + & ++ & + \\
\hline Thalamus & + & +++ & + & + & +++ & ++ & + & + & + & ++ \\
\hline Motor neurons & - & +++ & - & - & +++ & - & - & - & - & +++ \\
\hline
\end{tabular}

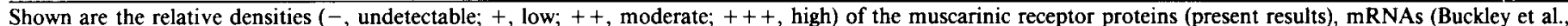

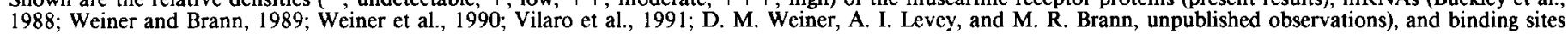

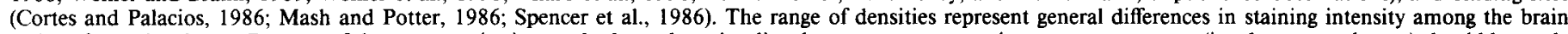

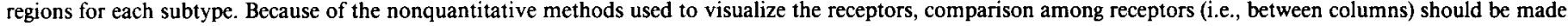
with caution.

and in particular, $\mathrm{M}_{1}$-selective antagonists impair memory in animals (Messer et al., 1990), the $\mathrm{m}_{1}$ - and $\mathrm{m}_{4}$-proteins must be considered as candidates for mediating these effects. Similarly, either or both of these receptor proteins in striatum may be responsible for the therapeutically important effects of $\mathbf{M}_{1}$-selective antagonists, such as trihexiphenidyl, in patients with Parkinson's disease and other movement disorders. Therefore, drugs targeted to only $\mathrm{m}_{1}$ or $\mathrm{m}_{4}$ have considerable potential for more effectively and specifically treating patients with Alzheimer's disease and Parkinson's disease.

The localization of $\mathrm{m}_{2}$-protein provides very strong evidence for the role of this subtype as an autoreceptor. Although muscarinic binding sites with low affinity for pirenzepine $\left(\mathrm{M}_{2}\right)$ were previously shown to be associated with cholinergic neurons and projections (Mash et al., 1985; Mash and Potter, 1986; Spencer et al., 1986) and to inhibit ACh release in cortex and hippocampus (Raiteri et al., 1984; Meyer and Otero, 1985; Quirion et al., 1989; Marchi et al., 1990), the genetic subtype responsible for this important function has not been well defincd. At lcast two receptor proteins, $\mathrm{m}_{2}$ and $\mathrm{m}_{4}$, bind $\mathrm{M}_{2}$-selective ligands with similar affinities (Buckley et al., 1989; Dorje et al., 1991); both proteins also have common signal transduction mechanisms that may be important in regulation of neurotransmitter release (Higashida et al., 1990). Moreover, the pharmacology of the autoreceptors has been variously described as $\mathbf{M}_{2}$ (Raiteri et al., 1984; Meyer and Otero, 1985; Quirion et al., 1989) or $\mathrm{M}_{3}$ (Marchi et al., 1990). In the present study, $\mathrm{m}_{2}$-receptor protein was associated with central cholinergic systems (Mesulam et al., 1983) in basal forebrain, striatum, mesopontine tegmentum, and cranial motor neurons; these results correlate extremely well with the expression of $\mathrm{m}_{2}$-mRNA (Buckley et al., 1988) and $\mathbf{M}_{2-}$ binding sites (Mash and Potter, 1986; Spencer et al., 1986). It is also important to note that our results indicate that $\mathrm{m}_{2}$-re- ceptor protein, as previously described for the mRNA (Buckley et al., 1988), is present in many noncholinergic cells and fibers in cortex, pontine nuclei, and ccrcbcllum. Therefore, at thesc sites the $m_{2}$ may function either postsynaptically or on noncholinergic nerve terminals to modulate release of other neurotransmitters.

In conclusion, this investigation demonstrates the distributions of the three most abundant muscarinic receptor subtype proteins in rat brain. Our combined molecular and immunological approach has allowed the selective localization of muscarinic receptor subtypes; this has not been possible with available pharmacological methods. Immunocytochemistry also allows a much higher degree of cellular resolution than possible with receptor autoradiography and can be extended to the ultrastructural level. Knowledge of the distributions of these receptors has helped to clarify the functional properties of genetically defined subtypes in neuronal circuits in brain. This information, together with the development of more selective muscarinic drugs, should lcad to more rational and effective treatments of many neurological and psychiatric diseases associated with dysfunction of cholinergic systems.

\section{References}

Akiba I, Kubo T, Maeda A, Bujo H, Nakai J, Mishina M, Numa S (1988) Primary structure of porcine muscarinic acetylcholine receptor III and antagonist binding studies. FFBS I ett 235:257-261.

Bonner TI, Buckley NJ, Young AC, Brann MR (1987) Identification of a family of muscarinic acetylcholine receptor genes. Science 237: $527-532$.

Bonner TI, Young AC, Brann MR, Buckley NJ (1988) Cloning and expression of the human and rat $\mathrm{m} 5$ muscarinic acetylcholine receptor genes. Neuron 1:403-410.

Brown E, Kendall DA, Nahorski SR (1984) Inositol phospholipid hydrolysis in rat cerebral cortical slices. 1. Receptor characterization. J Neurochem 42:1379-1387.

Figure 3. Examples of muscarinic receptor subtype immunoreactivity in various regions of rat brain. A parasagittal section through the rat thalamus, brainstem, and cerebellum is shown in $A$. The $\mathrm{m}_{2}$ receptor was the predominant subtype localized in these regions, in agreement with immunoprecipitation studies (Table 2). Note the intense immunoreactivity in the hippocampus ( $h i$ ), anteroventral nucleus of the thalamus $(t h$ ), anterior pretectal nucleus $(p t)$, superior $(s c)$ and inferior $(i c)$ colliculi, pontine nuclei $(p n)$, cerebellum $(c b)$, and trigeminal $(V)$ and facial $(V I I)$ motor nuclei. Examples of cellular localization of $\mathrm{m}_{2}$ receptor are shown in the striatum $(B)$ and basal forebrain $(D)$. The receptor appears to be localized predominantly in the perikaryal and dendritic membranes and, in addition, is present in the neuropil in both regions. The $\mathrm{m}_{1}$ receptor $(C)$ is present in many neurons in cortex. The $\mathrm{m}_{4}$ receptor $(E)$ appears localized at the membrane surface (arrow) of scattered neurons in cortex (predominantly layer $\mathrm{V}$ ) using an antibody reactive with denatured $\mathrm{m}_{4} \mathrm{i} 3$ (Levey et al., 1990) and silver intensified (Kitt et al., 1984). Scale bars: $\mathrm{A}, 350 \mu \mathrm{m} ; B, 14$ $\mu \mathrm{m} ; C$ and $E, 16 \mu \mathrm{m} ; D, 18 \mu \mathrm{m}$. 
Buckley NJ, Bonner TI, Brann MR (1988) Localization of a family of muscarinic receptor mRNAs in rat brain. J Neurosci 8:4646-4652.

Buckley NJ, Bonner TI, Buckley CM, Brann MR (1989) Antagonist binding properties of five cloned muscarinic receptors expressed in CHO-K 1 cells. Mol Pharmacol 35:469-476.

Cortes R, Palascios JM (1986) Muscarinic cholinergic receptor subtypes in the rat brain. I. Quantitative autoradiographic studies. Brain Res 362:227-238.

Doods HN, Mathy MJ, Davidesko D, van Charldorp KJ, de Jonge A, van Zwieten PA (1987) Selectivity of muscarinic antagonists in radioligand and in vivo experiments for the putative M1, M2 and M3 receptors. J Pharmacol Exp Ther 242:257-262.

Dorje F, Wess J, Lambrecht G, Tacke R, Mutschler E, Brann MR (1991) Antagonist binding profiles of five cloned human muscarinic receptor subtypes. J Pharmacol Exp Ther 256:727-733.

Dorje F, Levey AI, Brann MR (in press) Immunological detection of muscarinic receptor subtype proteins $(\mathrm{m} 1-\mathrm{m} 5)$ in rabbit peripheral tissues. Mol Pharmacol, in press.

Drachman DA, Leavitt JL (1974) Human memory and the cholinergic system. A relationship to aging? Arch Neurol 30:113-121.

Ehlert FJ, Tran LLP (1990) Regional distribution of M1, M2, and non-M1, non-M2 subtypes of muscarinic binding sites in rat brain. J Pharmacol Exp Ther 225:1148-1157.

Fukuda K, Higashida H, Kubo T, Maeda A, Akiba I, Bujo H, Mishina M, Numa S (1988) Selective coupling with $\mathrm{K}^{+}$currents of muscarinic acetylcholine receptor subtypes in NG 108-15 cells. Nature 335:355358.

Hammer R, Berrie CP, Birdsall NJM, Burgen ASV, Hulme EC (1980) Pirenzepine distinguishes between subclasses of muscarinic receptors. Nature 283:90-92.

Harlow D, Lane D (1988) Antibodies: a laboratory manual. Cold Spring Harbor, NY: Cold Spring Harbor Laboratory.

Higashida H, Hashii M, Fukuda K, Caulfield MP, Brown DA (1990) Selective coupling of different muscarinic acetylcholine receptors to neuronal calcium currents in DNA-transfected cells. Proc R Soc Lond [Biol] 242:68-74.

Hulme EC, Birdsall NJM, Buckley NJ (1990) Muscarinic receptor subtypes. Annu Rev Pharmacol Toxicol 30:633-73.

Jones SV, Barker JL, Bonner TI, Buckley NJ, Brann MR (1988a) Electrophysiological characterization of cloned $\mathrm{m} 1$ muscarinic receptors expressed in A9 L cells. Proc Natl Acad Sci USA 85:4056-4060.

Jones SV, Barker JL, Buckley NJ, Bonner TI, Collins RM, Brann MR (1988b) Cloned muscarinic receptor subtypes expressed in A9 L cells differ in their coupling to electrical responses. Mol Pharmacol 34: $421-426$

Kitt CA, Price DL, Struble RG, Cork LC, Wainer BH, Mobley WC (1984) Evidence for cholinergic neurites in senile plaques. Science 226:1443-1445

Kraft RJ, Tardoff KS, Krauter KS, Leinwand LA (1988) Using miniprep plasmid DNA for sequencing double-stranded templates with Sequenase. Biotechniques 6:544-546.

Kubo T, Fukuda K, Mikami A, Maeda A, Takahashi H, Mishina M, Haga T, Haga K, Ichiyama A, Kangawa K, Kojima M, Matsuo H, Hirose T, Numa S (1986) Cloning, sequencing and expression of complementary DNA encoding the muscarinic acetylcholine receptor. Nature 323:411-416.

Kuhar MJ, Yamamura HI (1975) Light microscopic autoradiographic localization of muscarinic receptors in rat brain by specific binding of a potent antagonist. Nature 253:560-561.

Levey AI, Stormann TM, Brann MR (1990) Bacterial expression of human muscarinic receptor fusion proteins and generation of subtypespecific antisera. FEBS Lett 275:65-69.

Luthin GR, Harkness I, Artymyshyn RP, Wolfe BB (1988) Antibodies to a synthetic peptide can be used to distinguish between muscarinic acetylcholine receptor binding sites in brain and heart. Mol Pharmacol 34:327-333.

Marchi M, Ruelle A, Andrioli GC, Raiteri M (1990) Pirenzepineinsensitive muscarinic autoreceptors regulate acetylcholine release in hurnan neocortex. Brain Res 520:347-350.
Mash DC, Potter LT (1986) Autoradiographic localization of MI and M2 muscarine receptors in the rat brain. Neuroscience 19:551-564.

Mash DC, Flynn DD, Potter LT (1985) Loss of M2 muscarine receptors in the cerebral cortex in Alzheimer's disease and experimental cholinergic denervation. Science 228:1115-1117.

McCormick DA, Prince DA (1985) Two types of muscarinic response to acetylcholine in mammalian cortical neurons. Proc Natl Acad Sci USA 82:6344-6348.

Messer WS, Bohnett M, Stibbe J (1990) Evidence for a preferential involvement of $\mathrm{M} 1$ muscarinic receptors in representational memory. Neurosci Lett 116:184-189.

Mesulam MM, Mufson EJ, Wainer BH, Levey AI (1983) Central cholinergic pathways in the rat: an overview based on an alternative nomenclature (Ch 1-Ch6). Neuroscience 10:1185-1201.

Meyer EM, Otero DH (1985) Pharmacological and ionic characterizations of the muscarinic receptors modulating $\left[{ }^{3} \mathrm{H}\right]$ acetylcholine release from rat cortical synaptosomes. J Neurosci 5:1202-1207.

Peralta EG, Ashkenazi A, Winslow JW, Smith DH, Ramachandran J, Capon DJ (1987) Distinct primary structures, ligand-binding properties and tissue-specific expression of four human muscarinic acetylcholine receptors. EMBO J 6:3923-3929.

Peralta EG, Ashkenazi A, Winslow JW, Ramachandran J, Capon DJ (1988) Differential regulation of PI hydrolysis and adenylyl cyclase by muscarinic receptor subtypes. Nature 334:434-437.

Quirion R, Aubert I, Lapchak PA, Schaum RP, Teolis S, Gauthier S, Araujo DM (1989) Muscarinic receptor subtypes in human neurodegenerative disorders: focus on Alzheimer's disease. Trends Pharmacol Sci [Suppl] 10:80-84.

Raiteri M, Leardi R, Marchi M (1984) Heterogeneity of presynaptic muscarinic receptors regulating neurotransmitter release in the rat brain. J Pharmacol Exp Ther 228:209-214.

Regenold W, Arujo D, Quirion R (1987) Direct visualization of brain M2 muscarinic receptors using the selective antagonist [ $\left.{ }^{3} \mathrm{H}\right] \mathrm{AF}-\mathrm{DX} 116$. Eur J Pharmacol 144:417-419.

Sambrook J, Fritsch EF, Maniatas T (1989) Molecular cloning: a laboratory manual. Cold Spring Harbor, NY: Cold Spring Harbor Press.

Smith DB, Johnson KS (1988) Single-step purification of polypeptides expressed in Escherichia coli as fusions with glutathione $S$-transferase. Gene 67:31-40.

Spencer DG Jr, Horvath E, Traber J (1986) Direct autoradiographic determination of $\mathrm{M} 1$ and $\mathrm{M} 2$ muscarinic acetylcholine receptor distribution in rat brain: relation to cholinergic nuclei and projections. Brain Res 380:59-68.

Vilaro MT, Wiederhold K-H, Palacios JM, Mengod G (1991) Muscarinic cholinergic receptors in the rat caudate-putamen and olfactory tubercle belong predominantly to the $\mathrm{m} 4$ class: in situ hybridization and receptor autoradiography. Neuroscience 40:159-167.

Waelbroeck M, Tastenoy M, Camus .I, Christophe .J (1990) Binding of selective antagonists to 4 muscarinic receptors (Ml to $M 4)$ in rat forebrain. Mol Pharmacol 38:267-273.

Wamsley JK, Gehlert DR, Roeske WR, Yamamura HI (1984) Muscarinic antagonist binding site heterogeneity as evidenced by autoradiography after direct labeling with $\left[{ }^{3} \mathrm{H}\right](-) \mathrm{QNB}$ and $\left[{ }^{3} \mathrm{H}\right]$ pirenzepine. Life Sci 34:1395-1402.

Weiner DM, Brann MR (1989) Distribution of m1-m5 muscarinic receptor mRNAs in rat brain. Trends Pharmacol Sci [Suppl] 10:115.

Weiner DM, Levey AI, Brann MR (1990) Expression of muscarinic acetylcholine and dopamine receptor mRNAs in rat basal ganglia. Proc Natl Acad Sci USA 87:7050-7054.

Wess J, Bonner TI, Dorje F, Brann MR (1990) Delineation of muscarinic receptor domains conferring selectivity of coupling to guanine nucleotide-binding proteins and 2nd messengers. Mol Pharmacol 38: $517-523$

Yamamura HI, Snyder SH (1974) Muscarinic cholinergic binding in rat brain. Proc Natl Acad Sci USA 71:1725-1729. 